\title{
油圧式パルセータ型疲労試験機の脈動波形の解析*
}

\author{
加 賀 屋 繁 治**
}

\section{The Analysis of Pulsating Wave of Hydraulic Pulsating Fatigue Testing Machine}

by

\section{Shigeji KAGAyA}

(Mori Testing Machine Co., Ltd., Tokyo)

\begin{abstract}
近年供試体が大型となり，特に曲げやねじり供試体に対してたわみ量の大きくとれる疲学試験機が各方面 から要望されるようになった。

これにてたえるためには1サイクルのパルセータ吐出量を大きくしなければならない．

とてろが使用者側としては大型供試体に限らず，ときには小さい供試体を小荷重，小振幅にて試験を行な "いたいととも生ずる，乙の場合はむしろ計測精度の高いととが望ましいので，小型パルセータにより試験を 行なうべきであるが，経済的見地からてれを許さないのが実情である.

これは大型パルセータでは小荷重，小振幅とすれば荷重波形がくずれて正確な荷重計測を行なうことがで きないからである。

本文はその原因の解析と，その対策として大ラムのなかに小ラムを併設して波形のくずれを除去するとと もに，あわせて経済運転を行なえるようにしたてとについて述べる。
\end{abstract}

\section{1 緒言}

最近, 電気的発振により供試体に任意の定状波形や ランダム波形を与える電気油圧サーボ升型疲労試験機 はわが国でも国産化されるようになり，疲労試験の分 野が拡大されるようになった。

とてろが，一方において正弦波のみに限定されるパ ルセータ型疲労試験機はほとんど変わらない需要があ る。乙れは疲労試験における荷重波形は正弦波のみに てよい場合が多いためである。

いま，上述の二つの疲労試験機により同一正弦波形 を与光る際の動力消費量を比較すると, 前者は後者よ り原理的にはるかに大きくなる。乙れは著者の設計に よる能力 $45 \sim 3 t$ の両者の疲労試験機の試験結果におい ても認められた。

したがって，疲労試験機を選定するときは試験の目 的やひん度によっていずれの型式を用いるかを決める べきである.

しかしながら，てのように動力的に有利であるパル セータ型疲学試験機によって負荷される波形は一般に 必ずしも正弦波形ではなく，振幅の大小によって波形 がくずれてくる、すなわち拢幅が小さく，しかも，荷 重が小さいときは異状先頭波形を描き，また，乙れは

* 原稿受理 昭和 41 年 9 月 5 日

** 正会員 (株) 森試験機製作所 東京都品川区束大崎 1 丁目
荷重計測に際して精度低下の原因ともなる。

ての傾向は最近の大型化しているパルセータ型疲労 試駼機においては特に顕著に現われる。

本研究は，乙の先頭波形を誘起する原因をパルセー タの構造について機構学的解析により明らかにしたも のである。また，乙の先頭波形を除去する対策と同調 弁の改良を実機てついて実施し, 動的の荷重計測精度 を向上させえたととについて報告する。

\section{2 脈動波形の解析}

\section{$2 \cdot 1$ 概 要}

脈動発生機により供試体に繰返し荷重を与える際の 伝達系統を図1 亿示す。

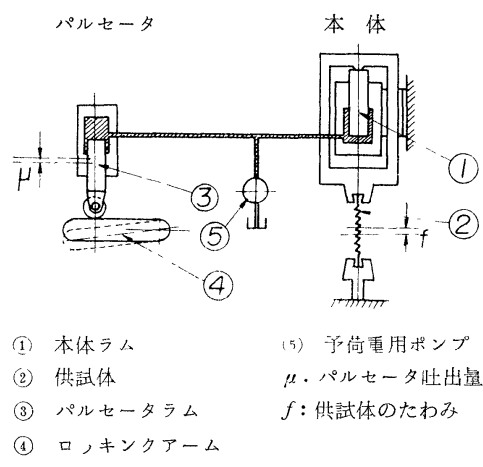

図1油王型疲労試験機の油圧系統 
ての図において支点を中心として動摇するロッキン グアーム(4)の上面にローラが接触し，ラム(3)上下運 動をなし，供試体に繰返し荷重が与えうれる。振幅の 設定は運転中に調整できる(3)の水平移動によるが，(4) の支点の直上にあるときは振幅は 0 であり,また, 左端 にあるときは最大となる。ラムの位置がロッキングア 一ムの左側汇あるときは供試体佂正弦波形が与えられ るが，供試体が短く，しかも，小荷重のときはラムは (4)の支点の近くに移動させなければならないが，ての ときは後述するように波形の上限荷重部分は先頭形と なり，下限荷重部分は扁平となる。乙れらの上下限の 油圧は同調回転弁の狭い油路を通して差圧計に伝達さ れるが，最高部分が先頭形となるのでわずかのフエー スラグや, タイムラグにより最高油圧を伝達すること がきわめてむずかしく，実荷重より低い荷重が差圧計 に伝達されるとととなり, てれが荷重の計測精度の低 下となる。なお，最低荷重は波形が偏平であるので， 荷重の計測精度の点では問題とならない.

\section{$2 \cdot 2$ ラムの運動の解析}

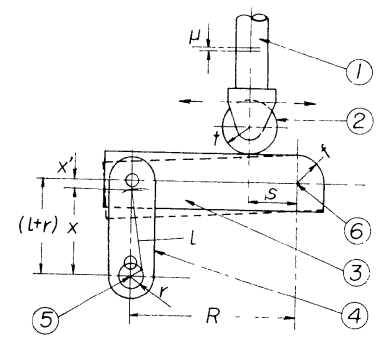

(1) パルセータラム (4) 連結桿

(2) ローラ (5) 偏心軸の中心

(3) ロノキンクアーム (6) ロノキンクアームの中心

図 2 パルセータの機構

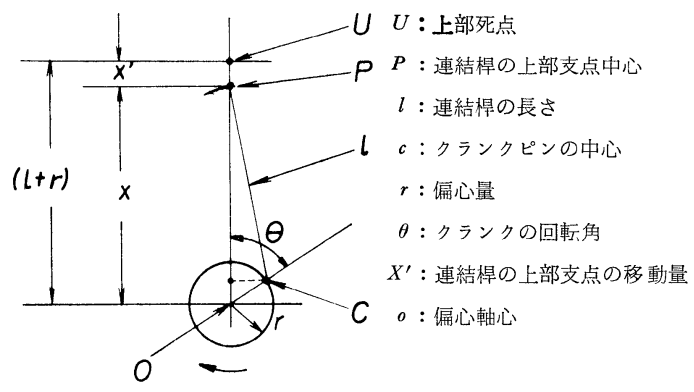

汹 3 パルセータのリンク機構

図 2 はラムの運動の状態を示す機構図で, 図 3 は偏 心軸と連結桿との連結状態を示したものである。乙れ らの図より上部コンネクテングロットの移動量 $X^{\prime}$ と, ロッキングアームの運動角 $\beta$ は次の式によって表わさ れる。

$$
X^{\prime}=r(1-\cos \theta)+r \frac{\rho}{4}(1-\cos 2 \theta)
$$

$$
X^{\prime}=R \sin \beta
$$

いま，乙の式をもとにロッキングアームの半径 $R$ の 全域にわたってラムの水平移動量 $s$ を変更させて運転 したときに描く脈動波形の解析を行なう。

$\mathbf{2} \cdot \mathbf{2} \cdot \mathbf{1} s>(\boldsymbol{f}+\boldsymbol{t}) \sin \boldsymbol{\beta}_{\max }$ の場合仳4亿おい て $\beta$ の変化とローラ中心の移動量 $\mu$ との関係は次式の ように誘導するととができる。

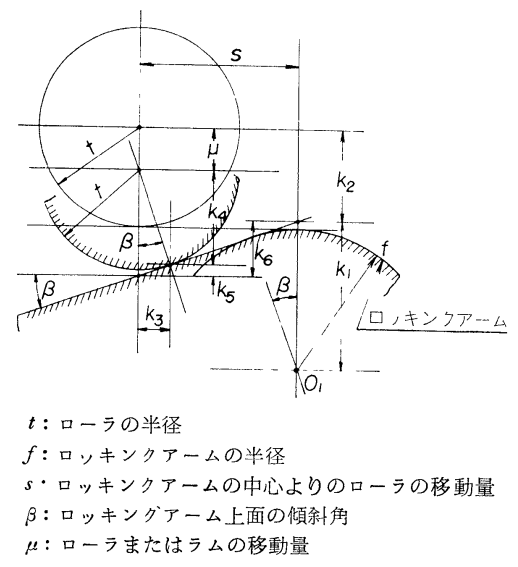

図 4 パルセータラムの運動機構 $\left(s>(f+t) \sin \beta_{\max }\right.$ の場合)

$$
\begin{aligned}
& \mu=k_{2}+k_{6}-k_{4}-k_{5} \\
& \therefore \mu=f\left(1-\frac{1}{\cos \beta}\right)+t+s \frac{\sin \beta}{\cos \beta} \\
& -t \cos \beta-t \frac{\sin ^{2} \beta}{\cos \beta}
\end{aligned}
$$

角 $\beta$ が小さので

$$
\cos \beta=1-1 / 2 \sin ^{2} \beta
$$

この值を(4)式に代入して整理すると，

$$
\begin{aligned}
& \mu=\frac{2}{2-\sin ^{2} \beta}\left(s \sin \beta-f-t \sin ^{2} \beta\right)+f \\
& +\frac{t}{2} \sin ^{2} \beta \\
& \text { ことに, } \quad m=\frac{2}{2-\sin ^{2} \beta}, n=t \sin ^{2} \beta \text { とおけば, } \\
& \quad \mu=m s \sin \beta-n(m-0.5)-f(m-1)
\end{aligned}
$$

(6)式はクランク角 $\omega t$ に応じてローラ中心が垂直に 移動する関係を表わすもので, 式中 $m$ は 1 より常に大 きい值である、また，第 1 項の $m s \sin \beta$ は半径 $f$ と $t$ が0で， $m$ の值が 1 亿近づく場合において， $\mu=s$ $\sin \beta$ となる基本形と一致する。 また, 第 2 , 第 3 項 の括弧内は常に正数であるので, 第 1 項から削減され， $s$ の值によって波形は正弦波（近似）より変化すること は了解できる。

$\mathbf{2} \cdot \mathbf{2} \cdot \mathbf{2} s<(\boldsymbol{f}+\boldsymbol{t}) \sin \boldsymbol{\beta}_{\max }$ の場合 この場合は ローラが中正位置 $0_{1}$ ， 亿接近している状態である.

$$
\alpha_{\max }=\sin ^{-1} \frac{s}{(f+t)}
$$




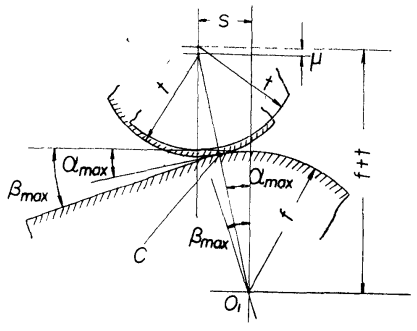

$c:$ 半径 $t$ と半径 $f$ の接点

図 5 パルセータラムの運動機構 $\left(s<(f+t) \sin \beta_{\max }\right.$ の場合 $)$

$\beta$ が $\alpha_{\max }$ より小さい角度の範囲の計算式は前項の (6)式による。しかし， $\alpha_{\max }$ をてえる部分，すなわち $\left(\beta_{\max }-\alpha_{\max }\right)$ の範井に対しては $\mathrm{C}$ 点において接触し ているのみであるから上下運動は起てさない。したが って, $\mathbf{2} \cdot \mathbf{2} \cdot \mathbf{1}$ の場合は2・2・2の場合と, 運動を起と さない部分の複合されたものである。

\section{$2 \cdot 3$ 波形の作図}

前項にわいて求めた計算式をもとに，大型パルセ一 タの一般に使用される寸法のものに対してクランクの 角 $\omega t$ に応ずるラムの各位置の波形を描けば図 6 のよ うである。
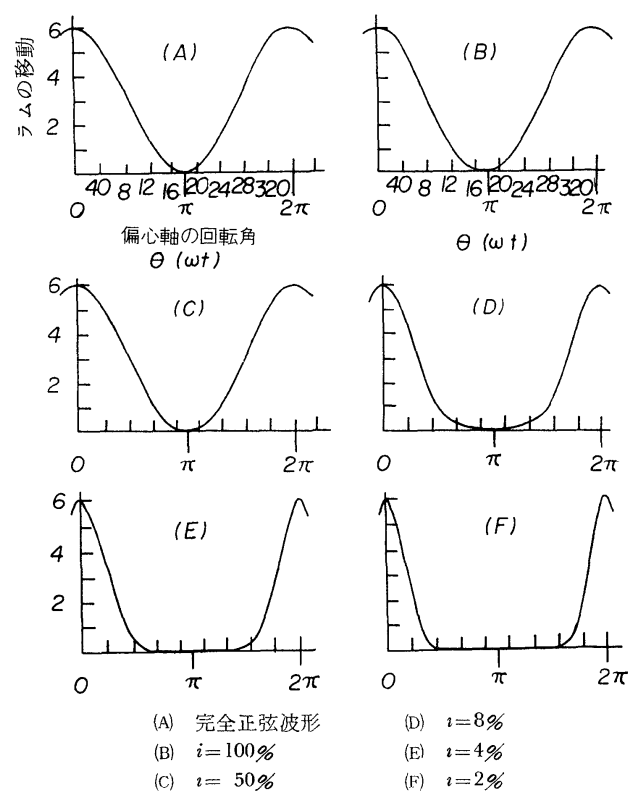

(D) $\imath=8 \%$

$\imath: S / R(\%)$

(E) $\imath=4 \%$

(F) $\imath=2 \%$

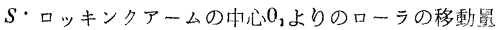
$R:$ ロッキンクアームの全長

図 6 ロッキングアームに対するローラ の各位圆にお教被形の比洨

この図でAは完全な正弦波形を表わし， $\mathrm{B}$ は $s$ の值 が全ストロークの100\%の位置におけるもので，以下， CDEF はそれぞれ50，8，4，および $2 \%$ の位置抒 ける波形である。
ての図で明らかなように，B， $\mathrm{C} は \mathrm{~A} の$ 完全正弦波 形とほとんど変わらない．D梳わ= $(f+t) \sin \beta_{\max }$ の 点のもので, 乙の付近では上限部において相当程度の

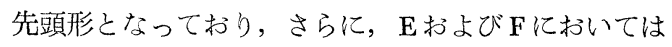
ての傾向が顕著に現われる。一方, 下限荷重部の偏平 度は上限荷重部の先頭度に比例して増大する。

\section{$2 \cdot 4$ 波形の検討}

上述のように B, G は論外として，Dは特殊三角波 に近く, また， $\mathrm{E}, \mathrm{F}$ は上部先頭形の三角形の衝撃波 に近い．との試験機の上下限の荷重は同調弁を通して 圧力計(差圧計) 亿伝えて正確に指示され，また指針か らの指令によって完全に荷重の自動制御を行なわなけ ればならない，また，運転中荷重計の指針ができるだ け振れないようにするため, 回転同調弁の弁体のみぞ の幅は狭くしなければならない，乙れを広くすれば指 針が振れるばかりでなく，乙の部分の荷重の平均值を 示すとととなる. また, 油圧系全体の圧力伝達の夕イ ムラグも含まれるので波形の先頭度が大きいほど荷重 の計測精度は低下する。

\section{3 先頭波形の除去と動的荷重精度向上の対策}

\section{$3 \cdot 1$ 二重ラム}

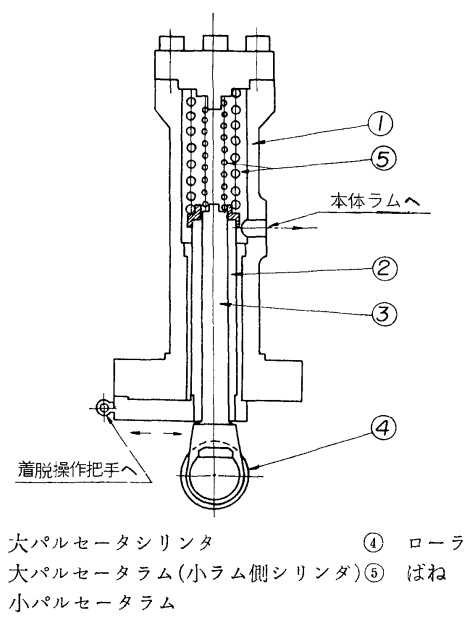

図7 二重ラムの構造図

大型構造物の疲労試験機として設計されたパルセ一 夕は特に大容量のものであるが，てのパルセー夕を使 用して，ときには小荷重，小振幅の供試体を試験する 場合も起とるととは当然と考光なければならない。ま た機戌的には振幅は 0 とするととは可能であり, 荷重 も最大能力の $1 / 20$ 程度の試験をするてとができるが， 小振幅とするときは前述の現象が現われる.

根本的には供試体汇適合するパルセータを採用する のを理想とするが，経済的理由からいっても困難なと とであって，小振幅のものに対しても試験ができると とが望ましい. 

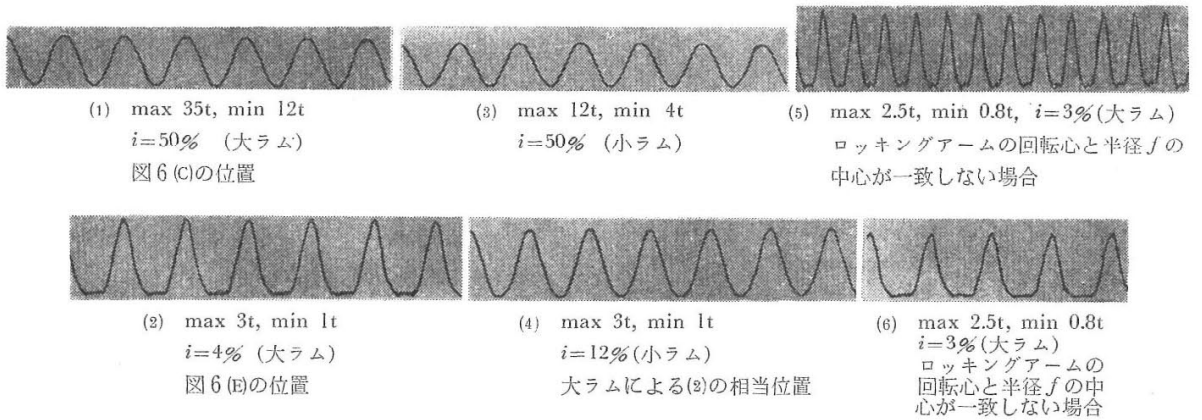

图 8 パルセータラムのロッキングアームに対する各位置の波形オシログラフ

との理由から，前述の DEF の付近では使用しないこ とをたてま光とする二重ラム方式学考案した。

図7において(3)は小ラム，(2)は小シリンダを備えた大 ラム，(1)はシリンダである。との大小ラムの容量比 はできるだけ大きいことが望ましいが，構造の関係で

$3: 1$ 程度か泿度である。

また，ての大小ラムの切換は, 外部より固定傾斜板 を着脱させる把手によって簢単に行なうことができる。

運転の際は，小容量のときは(3) ラムは単独運動をな し，大容量のときは(2)(3)のムが同時に遑動し，スプ リング(らは常にラムを上方より料す役めをする。

このよらな構造とすることは從来のものに小改造を 行ならことによって得られるもので, てれによって先 頭波形存除去し，荷重の計測精度死向上させるととも に，所琶動力の若干の節減花図りらるととは明らかで ある。

次に図 8 は従来のラムと二重ラムに改造を行なった ものによる試験において波形在オシログラフで描かせ たものの一例である。

このオシログラフの(1)は大シリンダのロッキングア 一 ム $R$ に対する水平移動量 $s$ 割合が $i=s ! R=50 \%$ における波北であって，(2)は同しく大シリンダの位置

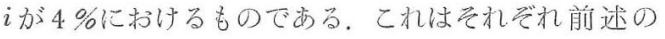
解析によって描いた図 6 の(C) と(E)に相当する波形であ 万.

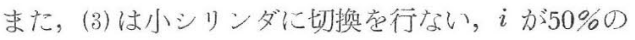

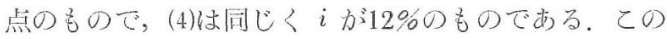
(4)は供試体に刘する試験条件は上述の(2)に相当し，小 シリンダに切り㒜えるとによって波形のくずれが完 全になくなっているとと表表わしている。次に(5)と(6) は大シリン多に预いて $i か ゙ 3 \% 00$ 点で，ロッキング アームの半径 $f \sigma$ 中心か，加工の不良から $R$ の回軽朝 心よりいくぶんずれている状態の一例在示したもので ある。すなおち，波形の下方の中央部に一つ小小波形 か扣えられている。てれは前述の解析によってもとの ような現象か現われる。この場合は，止力計に正碓な
下限荷重を指示することができないので加工は正確に すべきである。

\section{$3 \cdot 2$ 同調弁の位相の調整}

ロードセルの採用によって電気的指示計によれば, 油圧の計測はラフなめやすでよいといら説はあるが， 一応恝めら机るととである。しかしながら試験機を 取り扱う今々は，油圧計の及を信頼して計測する場合 はきわめて多いことが実情である。

また，ストレーンゲージの寿命や，電気的計器の経 斎的負担の面から考えても信頼できる油压指示計とす るととが望ましい，そとで，前述の二重うム方式の採 用によって，一応の目的を達したが，さらに荷重の計 測精度を向上させるため，同調弁の位相調整を行なら ことを試みた。

$3 \cdot 2 \cdot 1$ 運転時調整型図9の(2)(3)(

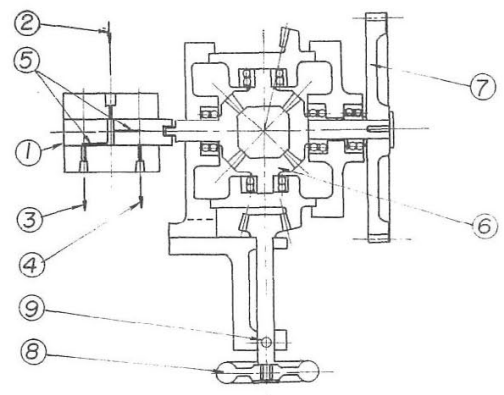
(1) 同調弁
(2) 本体ラムよりの油圧管
(3) 動力計へ (上限荷重)
(1) 動力計へ (下限荷望)
(5)同調弁のみぞ
(6) 差動蔺咕

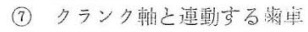 (娍速比1/2)
(8) 微調整ハンドル
(9) セットねじ

因 9 问調弁の位相角調整装遗（その1）

ぱ系路を示しているか⿱，同調升の狭い幅の油路より伍 ぱされる油压は，繰返し速さや，管内の压打，油王胝 抗，只の他によってタイムラグは多少異にする。この タイムラグは同調升の位相差となって上下限の荷重は 正確に指示評に伝達されない，との位相差をなくすた め同調弁体の油路の関係位置を運転中に調整できる機 
棈とすることは理想的である.

図 8 はこの目的のために考案したもので,パルセー 夕軸と同調して回転するギャ(7)の回転によって，(6)差 動菡車を通して(1)の弁体が回転する.

いま，8把手の微調整により差動隶車を介して，(1) を前進または後退させて, 指示計を見ながら最大值を 検出しようとするものである．調整完了後は(9)の固定 ねじにより絞めつける。

この方式は理想とするが，機構が多少複難であるの で実機にはまだ採用していない。

$3 \cdot 2 \cdot 2$ 停止時調整型 図1006は似ルセー夕軸



(1) 闰調弁

(5) 同調弁のみそ

(2) 本体ラムよりの伷圧管

(6)クランク軸と連動する歯車

(3) 動力計へ（上限荷重）

(7) 位相角潤整円板

(4) 動力計へ（下限荷重）

(8) 七ノトねし

図10同調弁の位相角調整装籄（その 2)

と同調して回転するギヤで，弁体(1)と闹一位相にある (7)の円板とは8(8)固定ボルトにより締結される. (6)，(7) にはきわめてゆるやかな角度を持つ半径方向の長穴が あり，ての穴に沿って8を移動させて固定するてとに より微調整を行ないうる。

この方式は場合に忘じてトライアルを行なわなけれ ばならない不便を生じたが，一応の成果をあげている。

\section{4 二重ラムとした場合の荷重精度の向上}

二重ラムの採用により, 四6 DEF の場合において 荷重の精度が向上する割合を表 I に示す。ここでLは 大ラムで， $S$ は $L 1 / 3$ 容量の小ラムである。なお， ここに示された值はスリットの幅が $1 \mathrm{~mm}$ とした場合 のおのおのの理論值である.

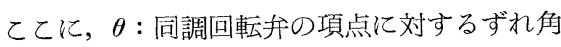
$\varepsilon:$ 頂点に対する $\theta$ 亿おける誤差率

実機についてはだいたいこの傾向を示し， E Fにお
表 I 単一ラムと二重ラムによる 荷重計測精度の比較

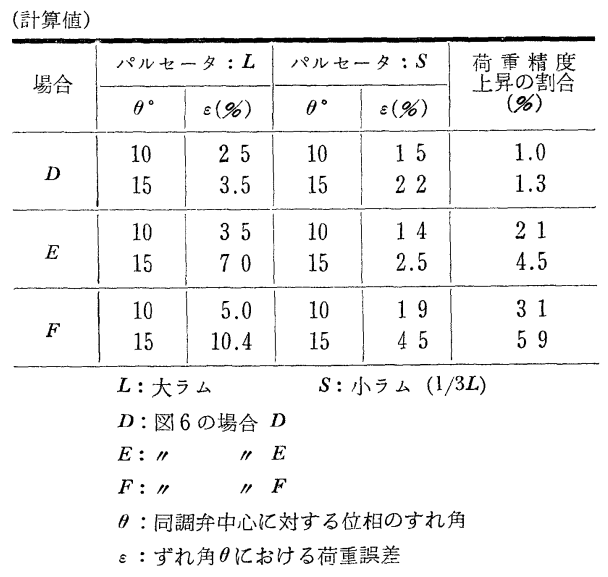

いて $2 \sim 6 \%$ 精度の向上をみた。 さらに位相角調整 装置の併用によって精度は向上されたが，ここにはこ れを加えていない，

\section{5 結言}

最近のパルセータは構造物を対象とするものが多い ため大型化しているので，小荷重，小振幅の材料の疲 労試験には適応しないのが央情である.

したがって前述の解析により，ロッキングアームを 長くするか， $f$ と $t$ の半径を小さくするととにより, 小振幅時の先頭波形の度合いを小さくするととはでき るが，構造上の制限や，面圧が過大となるなどの理由 である程度の限度がある。

本研究により $s$ 位置はだいたい $S \geqq(f+t) \sin$ $\beta_{\max } \times 1.5$ 以上にて運転すべきであるとの結論を得た ので，大型パルセータに対しては，上述の二重ラム型 式を採用して異状先頭波形を除去することができた。

また，乙れに加えて，同調弁の位相角調整機構を併 用し，荷重の計測精度を向上させるとともに，大小ラ ムの適正な採用によって動力的にも経済運転をなしえ たものと信ずる

(昭和41年 5 月 19 日 日本材料学会第 15 期総会講淀会にて講摍)

参考 文 献

1）加賀屋繁治，材料， 15，238（1966）. 